\title{
Penerapan Strategi Cost Efficiency (Efisiensi Biaya) Pada PT Bank Muamalat Indonesia, Tbk. Tahun 2017
}

\author{
Nidaul Izzah, Muhammad Zakaria Rachmawan \\ Institut Ilmu Sosial dan Manajemen Stiami \\ Email : nida.achis@yahoo.com, muhzakariaa@gmail.com
}

\section{ARTICLE INFO}

Keywords

Strategi, Efisiensi, Biaya

\section{ABSTRACT}

This research discusses about the implementation of the cost efficiency strategy at PT Bank Muamalat Indonesia, Tbk. As for the phenomenon of the problem that the authors observe on the financial ratios report of PT Bank Muamalat Indonesia, Tbk., especially in the BOPO ratio (Operating Costs to Operating Income), it ranks fourth highest out of a total of 13 Islamic Commercial Banks in Indonesia. Based on the authors' observation, it has implemented the cost efficiency strategy that is also carried out by banks in general. However, there are some obstacles that result in inefficient bank performance, so the BOPO ratio is still high. Therefore, PT Bank Muamalat Indonesia, Tbk. has made several solutions to overcome the obstacles faced.

\section{PENDAHULUAN}

Kegiatan perekonomian serta pemenuhan kebutuhan pada saat ini tidak terlepas dari sebuah lembaga keuangan yang dinamakan industri perbankan. Di era globalisasi sekarang ini, hampir semua transaksi yang berkaitan dengan keuangan dilakukan melalui industri perbankan. Mulai dari kegiatan bisnis dan perekonomian seperti jual beli atau perdagangan, hingga pembayaran kebutuhan rumah tangga seperti pembayaran tagihan air dan listrik, dan macam-macam transaksi lainnya, semua kini dapat dilakukan melalui industri perbankan. Oleh karena itu, perbankan saat ini menjadi lembaga keuangan yang memiliki peranan vital sebab perbankan berperan mendukung kegiatan perekonomian dan pemenuhan kebutuhan khususnya dalam melakukan transaksi, kita membutuhkan bank sebagai perantara keuangan guna melancarkan segala lalu lintas pembayaran yang hendak dilakukan.

Pengertian bank menurut Undang-Undang Perbankan No. 10 tahun 1998 yaitu badan usaha yang menghimpun dana dari masyarakat dalam bentuk simpanan dan menyalurkannya kepada masyarakat dalam bentuk kredit dalam rangka meningkatkan taraf hidup rakyat banyak. Di samping peran bank menghimpun dana dan menyalurkan dana, bank juga dapat berperan dalam memberikan jasa-jasa keuangan lainnya.

Di Indonesia, bank umum terdiri dari dua jenis bank, yaitu bank umum konvensional dan bank umum syariah. Kedua jenis bank ini pada dasarnya sama, secara garis besar yaitu sebagai intermediary financial. Perbedaannya dengan bank konvensional yaitu kegiatan operasional bank syariah kinerjanya berdasarkan syariat Islam yang mengacu pada Quran dan Hadits, lalu ada beberapa jasa perbankan syariah yang tidak dimiliki bank konvensional, serta memiliki lembaga pengawas yang tidak dimiliki oleh bank konvensional yang bertugas memonitor kinerja perbankan syariah yang disebut sebagai DPS (Dewan Pengawas Syariah). Melihat peranan perbankan yang penting seperti sekarang ini, banyak bermunculan macam-macam bank untuk memfasilitasi kebutuhan masyarakat akan transaksi yang berkaitan dengan keuangan. Banyaknya bankbank syariah baru menyebabkan terjadinya persaingan yang ketat antar bank dalam mendapatkan nasabah. Hal ini membuat bank-bank syariah berusaha memberikan pelayanan terbaik mengingat produk maupun jasa yang dimiliki bank-bank syariah pada umumnya hampir sama. Salah satu cara untuk memberikan pelayanan terbaik kepada nasabah yaitu berupa memperluas jaringan atau kantor cabang guna memfasilitasi agar nasabah dimudahkan dalam melakukan transaksi keuangan dimana pun berada. Bank syariah yang memiliki jaringan tersebar luas dan merata maka bank syariah tersebut mampu memenangkan persaingan di mata para 
nasabah. Sebab bank syariah tersebut mampu memberikan kepuasan dalam hal kemudahan bertransaksi dikarenakan jaringan yang mudah dijumpai. Nasabah akan merasa terpuaskan jika pelayanan yang diberikan sesuai yang diharapkan atau bahkan melebihi yang dibayangkan nasabah.

Namun sebenarnya, bank yang mampu memenangkan persaingan, bank yang sehat dan dapat bertahan di tengah persaingan yang ketat bukanlah bank yang memiliki persebaran jaringan atau kantor cabang di mana-mana, bukanlah bank yang memiliki gedung yang besar, megah, dan mewah. Namun, bank yang sehat dan mampu memenangkan persaingan serta dapat bertahan di tengah ketatnya persaingan antar bank yaitu bank yang memiliki indikator tingkat kesehatan bank yang baik. Tingkat kesehatan bank yang baik yaitu tingkat kesehatan bank yang sesuai dengan standar atau lebih baik dari yang ditetapkan oleh BI (Bank Indonesia). Salah satunya yaitu rasio BOPO (Biaya Operasional terhadap Pendapatan Operasional).

Dalam pengamatan ini, penulis memilih PT Bank Muamalat Indonesia, Tbk. sebagai obyek pengamatan. Selama magang kerja, penulis mengamati bahwa pada laporan rasio keuangan PT Bank Muamalat Indonesia, Tbk., khususnya pada rasio BOPO (Biaya Operasional terhadap Pendapatan Operasional), PT Bank Muamalat Indonesia, Tbk. menempati urutan keempat tertinggi dari total 13 Bank Umum Syariah yang ada di Indonesia. Hal ini tentu tidak baik bagi bank, sebab semakin tinggi rasio BOPO, semakin tidak efisien operasional suatu bank.

Berdasarkan latar belakang masalah yang telah dikemukakan di atas, penulis tertarik untuk membuat Tugas Akhir dengan judul "Penerapan Strategi Cost Efficiency (Efisiensi Biaya) pada PT Bank Muamalat Indonesia, Tbk. Tahun 2017".

\section{Fokus Pengamatan}

Berdasarkan latar belakang yang telah diuraikan di atas, maka fokus pengamatan yang menjadi dasar dalam penyusunan laporan Tugas Akhir ini yaitu: Bagaimana penerapan strategi efisiensi biaya pada PT Bank Muamalat Indonesia, Tbk.?

\section{Tujuan Pengamatan}

Adapun tujuan dari pengamatan yang penulis lakukan pada PT Bank Muamalat Indonesia, Tbk. khususnya di bagian Coorporate Strategy Planning yaitu: Untuk mengetahui penerapan strategi efisiensi biaya pada PT Bank Muamalat Indonesia, Tbk.

\section{Tinjauan Literatur}

\section{Strategi}

Porter (Pella, 2016:13) mengemukakan, Strategi adalah sekumpulan tindakan atau aktivitas yang berbeda untuk menghantarkan nilai organisasi yang unik agar organisasi dapat terus meningkatkan laba, terus berkembang dan bersaing di industri.

Wheelen dan Hunger (Pella, 2016:13) mengemukakan, Strategi adalah rumusan perencanaan komprehensif mengenai metode organisasi dalam memaksimalkan keunggulan kompetitif untuk mencapai misi dan visinya.

Glueck (Amirullah, 2015:4) mengemukakan, Strategi adalah sebuah rencana yang disatukan, luas, dan terintegrasi yang menghubungkan keunggulan strategi perusahaan dengan tantangan lingkungan dan yang dirancang untuk memastikan bahwa tujuan utama perusahaan itu dapat dicapai melalui pelaksanaan yang tepat oleh organisasi.

Pearce dan Robinson (Amirullah, 2015:4) mengemukakan, Strategi adalah rencana manajer yang berskala besar dan berorientasi kepada masa depan untuk berinteraksi dengan lingkungan persaingan guna mencapai sasaran-sasaran perusahaan.

Dari beberapa definisi yang telah dipaparkan, penulis menyimpulkan bahwa strategi adalah sebuah pemikiran yang dirancang, terdiri dari sekumpulan perencanaan yang berorientasi ke masa yang akan datang guna mewujudkan tujuan yang hendak dicapai oleh suatu lembaga, instansi, atau perusahaan, serta untuk menghadapi situasi dan kondisi di masa yang akan datang.

\section{Efisiensi (Efficiency)}

Menurut Makmur (2013:164), "Efisiensi adalah suatu usaha atau tindakan di mana seluruh komponen input yang dimanfaatkan dapat menciptakan seluruh komponen output dengan keseimbangan yang baik.". Gie (Priansa dan Garnida, 2015:15) mengemukakan, "Efisiensi adalah suatu asas dasar tentang perbandingan terbaik antara suatu usaha dengan hasilnya.". Perbandingan ini dapat dilihat dari dua segi, yaitu: 


\section{1) Segi Usaha}

Suatu kegiatan dapat dikatakan efisien kalau sesuatu hasil tertentu tercapai dengan usaha yang sekecil-kecilnya. Pengertian usaha dapat dikembalikan pada lima unsur yang dapat juga disebut sumbersumber kerja, yaitu pikiran, tenaga, waktu, ruang, dan benda (termasuk uang).

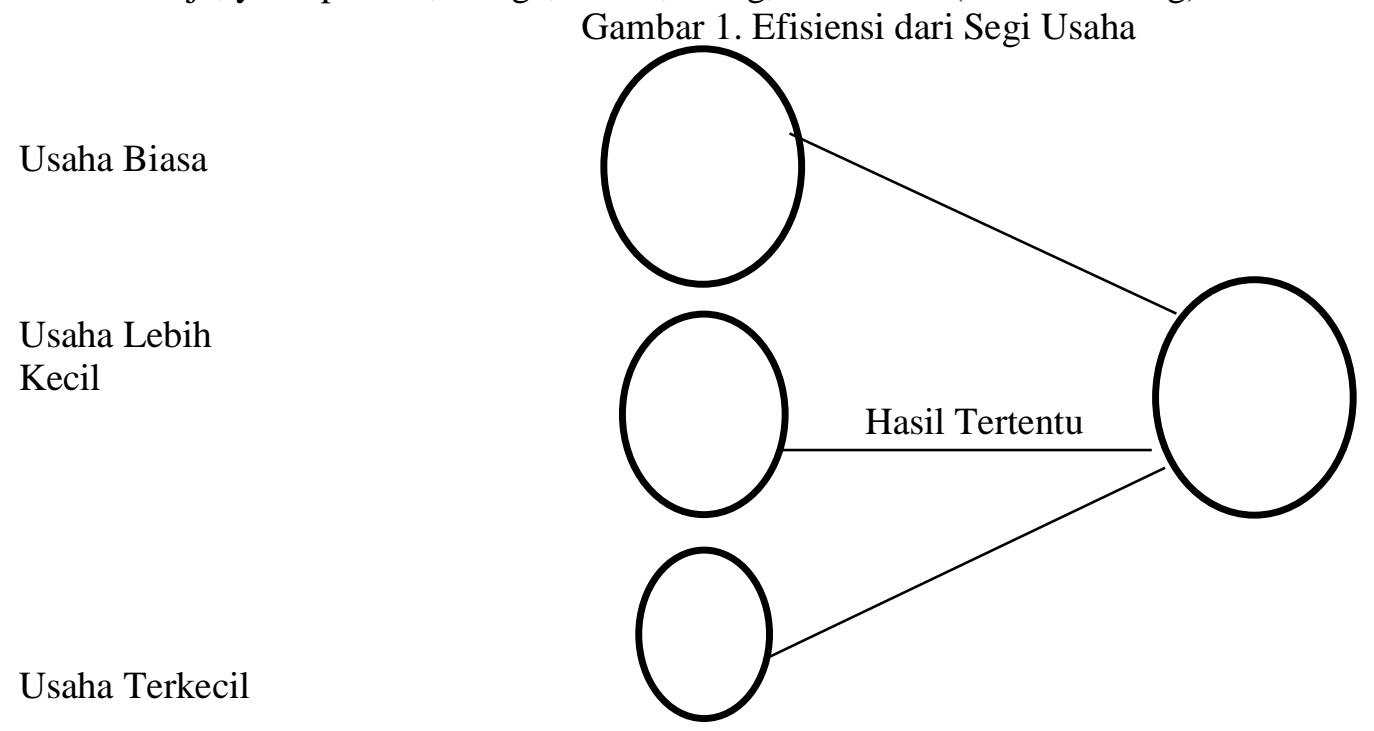

Sumber: Priansa dan Garnida. 2015. Manajemen Perkantoran Efektif, Efisien, dan Profesional.

Usaha huruf $\mathrm{C}$ adalah yang efisien karena memberikan perbandingan yang terbaik dilihat dari sudut usaha, yaitu paling sedikit mengeluarkan lima sumber kerja untuk mencapai hasil tertentu yang diharapkan.

2) Segi Hasil

Suatu kegiatan dapat disebut efisien kalau dengan suatu usaha tertentu memberikan hasil yang sebanyak-banyaknya, baik yang mengenai mutunya ataupun jumlah satuan hasil itu.

Gambar 2. Efisiensi dari Segi Hasil

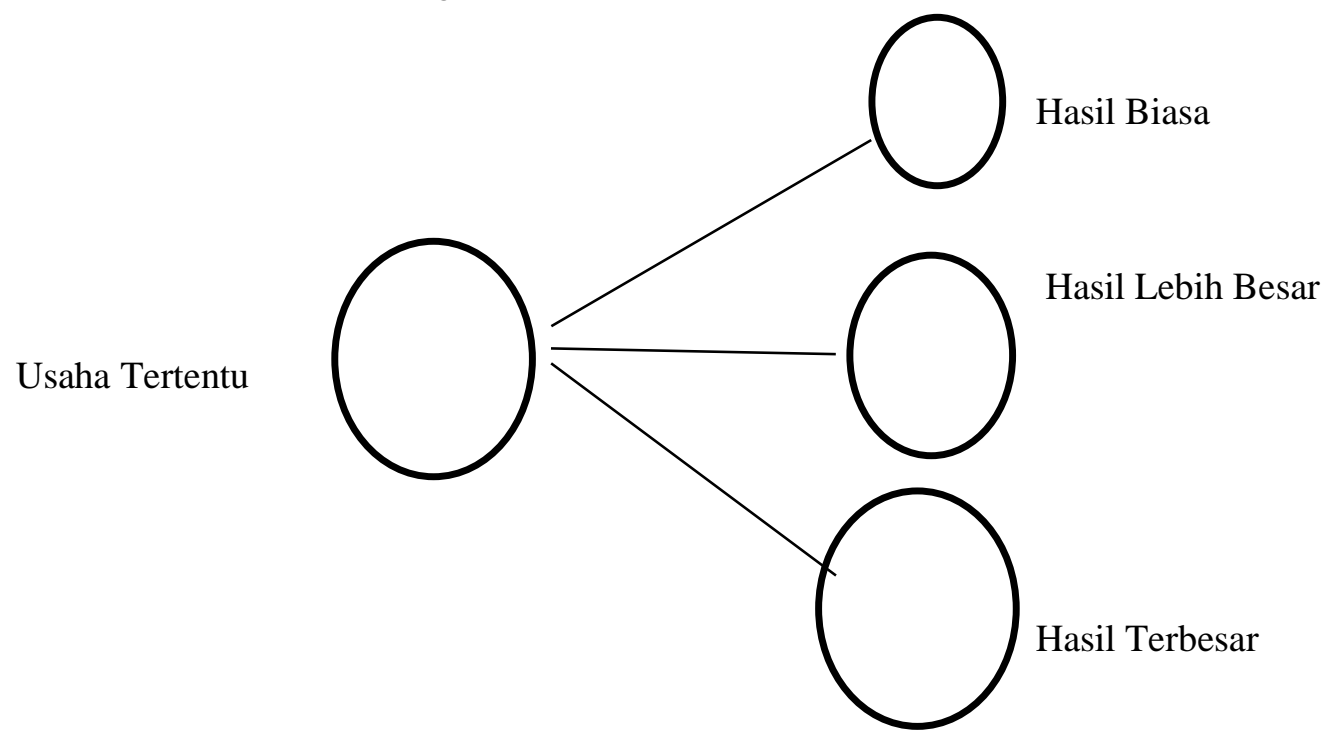

Sumber: Priansa dan Garnida. 2015. Manajemen Perkantoran Efektif, Efisien, dan Profesional.

Hasil huruf $\mathrm{C}$ adalah yang efisien karena menunjukan perbandingan yang terbaik ditinjau dari sudut hasil yang paling besar mengenai jumlah atau mutunya.

Sedarmayanti (Priansa dan Garnida, 2015:16) mengemukakan, Efisiensi merupakan pelaksanaan cara-cara tertentu dengan tanpa mengurangi tujuannya merupakan cara yang termudah mengerjakannya, termurah biayanya, tersingkat waktunya, teringan bebannya, terpendek jaraknya. 
Dari beberapa definisi di atas, penulis menyimpulkan bahwa efisiensi adalah suatu tindakan yang dilakukan untuk mencapai suatu tujuan dengan usaha yang sekecil-kecilnya dan memperoleh hasil yang maksimal.

\section{a. Asas-Asas Efisiensi}

Menurut Sedarmayanti (2017:133), asas-asas efisiensi ada 5 (lima), yaitu:

1) Asas Perencanaan

Merencanakan berarti menggambarkan dimuka mengenai tindakan-tindakan yang akan dilaksanakan dalam rangka mencapai suatu tujuan.

2) Asas Penyederhanaan

Menyederhanakan berarti membuat suatu sistem yang ruwet atau pekerjaan yang sukar menjadi lebih mudah atau ringan.

3) Asas Penghematan

Menghemat berarti mencegah pemakaian benda atau bahan secara berlebihan, sehingga biaya pekerjaan termaksud menjadi tidak mahal.

4) Asas Penghapusan

Menghapuskan berarti meniadakan kegiatan dalam melaksanakan suatu pekerjaan yang dianggap kurang perlu atau tidak berhubungan dengan hasil kerja yang ingin dicapai.

5) Asas Penggabungan

Menggabungkan berarti mempersatukan pekerjaan-pekerjaan yang memiliki persamaan atau bahanbahan yang mungkin dapat dikerjakan sekaligus dalam satu langkah, sehingga dapat menghemat waktu kerja.

\section{b. Syarat Efisiensi}

Menurut Sedarmayanti (2017:133), syarat dapat dicapainya efisiensi:

1) Berhasil guna atau efektif.

Yaitu untuk menyatakan bahwa kegiatan telah dilaksanakan dengan tepat, artinya target tercapai sesuai dengan waktu yang ditetapkan.

2) Ekonomis.

Ialah untuk menyebutkan bahwa di dalam usaha pencapaian efektif termaksud maka biaya, tenaga kerja, material, peralatan, waktu, ruangan, dan lain-lainnya telah dipergunakan dengan setepat-tepatnya.

3) Pelaksanaan kerja yang dapat dipertanggungjawabkan.

Yakni untuk membuktikan bahwa di dalam pelaksanaan kerja, sumber-sumber telah dimanfaatkan dengan setepat-tepatnya dan dilaksanakan penuh tanggung jawab sesuai dengan yang telah ditetapkan.

\section{Biaya (Cost)}

Carter (Salman, 2016:24) mengemukakan, "Biaya (cost) didefinisikan sebagai suatu nilai tukar, pengeluaran, pengorbanan yang dilakukan untuk menjamin perolehan manfaat.". Horngren et al. (Salman, 2016:24) mengemukakan,

Biaya (cost) didefinisikan sebagai suatu sumber daya yang dikorbankan (sacrificed) atau dilepaskan (forgone) untuk mencapai tujuan tertentu. Sumber daya yang dikorbankan dapat berupa bahan baku, tenaga kerja langsung, bahan pembantu, bahan penolong, tenaga kerja tidak langsung dan biaya produksi lainnya di luar bahan dan tenaga kerja. Biaya-biaya tersebut diukur dengan satuan mata uang, dapat berupa pengurangan aktiva, atau penambahan utang. Tujuan tertentu yang dimaksud dari definisi biaya di atas adalah dapat berupa barang jadi telah laku terjual, telah terjadi penggunaan aset atau pemanfaatan dalam bentuk lainnya.

Menurut Firmansyah (2014:25), "Secara luas, biaya mengandung arti pengorbanan sumber ekonomi yang dapat diukur dalam satuan uang, baik yang telah terjadi maupun yang akan terjadi untuk tujuan tertentu.". Dari paparan di atas, tampak bahwa biaya memiliki unsur sebagai berikut:

1) Biaya merupakan pengorbanan sumber ekonomi.

2) Biaya dapat diukur dengan satuan rupiah.

3) Biaya merupakan pengorbanan yang telah terjadi atau akan terjadi.

4) Biaya merupakan pengorbanan yang mempunyai tujuan. 
Dari beberapa definisi di atas, penulis menyimpulkan bahwa biaya adalah sesuatu yang dikorbankan atau dikeluarkan yang dapat diukur dengan satuan uang untuk memperoleh manfaat tertentu atau untuk tujuan tertentu.

Menurut Halim (2016:11), biaya-biaya yang dikumpulkan sesuai dengan golongan atau klasifikasi yang diinginkan, kemudian disajikan dan dianalisa, akan sangat bermanfaat bagi manajemen. Data biaya tersebut akan dapat dimanfaatkan oleh manajemen untuk berbagai tujuan.

Manfaat dari data biaya antara lain: untuk tujuan-tujuan pengawasan, membantu dalam penetapan harga jual, untuk menghitung rugi-laba periodik, untuk pengendalian biaya, untuk pengambilan keputusan.

Dari manfaat-manfaat data biaya yang telah dikemukakan di atas terlihat jelas bahwa data biaya itu berhubungan dengan masa lalu, masa sekarang dan masa yang akan datang. Perhitungan rugi-laba periodik termasuk di dalamnya penentuan nilai persediaan berhubungan dengan masa lalu. Pengendalian biaya berhubungan dengan masa sekarang, perencanaan, strategi harga dan analisa data biaya untuk pembuatan keputusan berhubungan dengan masa yang akan datang.

\section{METODE PENELITIAN}

Pendekatan dalam penelitian ini adalah penelitian kualitatif. Penelitian ini berusaha mendeskripsikan Penerapan Strategi Cost Efficiency (Efisiensi Biaya) pada PT Bank Muamalat Indonesia, Tbk. Tahun 2017. Selain itu dalam penelitian ini peneliti sebagai instrumen utama karena peneliti yang merencanakan, melaksanakan, mengumpulkan data, menganalisis data, menarik kesimpulan, dan membuat laporan. Oleh karena itu pendekatan yang digunakan dalam penelitian ini adalah pendekatan kualitatif. Pengumpulan data dilakukan melalui observasi dan wawancara.

\section{HASIL DAN PEMBAHASAN}

Di tengah persaingan perusahaan berusaha memperoleh laba/keuntungan sebesar-besarnya, terkadang laba/keuntungan yang diperoleh perusahaan masih dirasa kurang maksimal, atau bahkan tidak sesuai yang diharapkan. Hal ini karena laba/keuntungan merupakan faktor eksternal perusahaan, artinya tidak dapat dipastikan jumlahnya/besarnya. Maka pada umumnya perusahaan-perusahaan memanfaatkan faktor internal untuk meningkatkan laba/keuntungan, yaitu salah satu caranya dengan melakukan penerapan penghematan biaya-biaya perusahaan (cost efficiency). Begitu pun yang dilakukan oleh PT Bank Muamalat Indonesia, Tbk. dalam upaya memaksimalkan laba/keuntungan. Berikut ini upaya-upaya penerapan cost efficiency yang dilakukan oleh PT Bank Muamalat Indonesia, Tbk.:

\section{Penerapan Strategi Efisiensi Biaya (Cost Efficiency) pada PT Bank Muamalat Indonesia, Tbk.}

a. Penutupan jaringan (kantor-kantor cabang) yang kurang produktif

Dalam upaya memperluas jaringan atau kantor-kantor cabang, PT Bank Muamalat Indonesia, Tbk. tidak selalu berasumsi bahwa semakin bertambahnya persebaran jumlah kantor cabang, maka semakin besar pendapatan yang diperoleh dari hasil transaksi-transaksi yang dilakukan pada kantorkantor cabang tersebut. PT Bank Muamalat Indonesia, Tbk. tidak melupakan semakin banyak kantorkantor cabang didirikan, semakin besar pula biaya-biaya yang dikeluarkan bank untuk mendirikan dan mengoperasikan kantor-kantor cabang. Dalam mendirikan kantor cabang, terdapat biaya-biaya yang dikeluarkan PT Bank Muamalat Indonesia, Tbk. seperti biaya pembangunan/pendirian gedung, atau jika menyewa maka menjadi biaya sewa gedung, biaya listrik air dan telepon, upah tenaga kerja, serta biaya peralatan dan perlengkapan kantor. Biaya-biaya tersebut dipertimbangkan oleh PT Bank Muamalat Indonesia, Tbk., apakah biaya-biaya yang sudah dikeluarkan oleh bank sebanding dengan pendapatan yang diperoleh, PT Bank Muamalat Indonesia, Tbk. mempertimbangkan apakah dengan membuka kantor cabang pada suatu lokasi menghasilkan laba (produktif) dari banyaknya transaksitransaksi yang dilakukan nasabah dan pembukaan rekening, atau justru malah sebaliknya. Oleh karena itu, apabila PT Bank Muamalat Indonesia, Tbk. menemukan kondisi kantor cabang yang dianggap tidak efisien (kurang produktif), yaitu dalam penempatan kantor cabang pada suatu lokasi, jarang nasabah yang berkunjung untuk melakukan transaksi, membuka rekening/menjaring nasabah baru, maupun untuk keperluan lainnya yang berhubungan dengan bank, maka PT Bank Muamalat Indonesia, Tbk. akan melakukan penutupan kantor cabang tersebut guna menghemat biaya-biaya terkait operasional kantor cabang yang kurang produktif.

Nidaul Izzah ... (Penerapan Strategi Cost Efficiency (Efisiensi Biaya) Pada Pt Bank Muamalat ...) 
b. Pengurangan jumlah penyebaran mesin-mesin ATM

Penyebaran mesin-mesin ATM juga dipertimbangkan efisiensi keberadaannya oleh PT Bank Muamalat Indonesia, Tbk. Untuk menempatkan sebuah mesin ATM, bank mengeluarkan biaya sewa mesin ATM, biaya sewa tempat mesin ATM, biaya perawatan mesin ATM, upah tenaga kerja teknisi mesin ATM, serta upah petugas keamanan saat dilakukan pengisian uang ke mesin ATM. PT Bank Muamalat Indonesia, Tbk. mempertimbangkan apakah dengan menempatkan mesin ATM di suatu lokasi berikut dengan biaya-biaya yang dikeluarkan apakah sebanding dengan penggunaan mesin ATM tersebut, PT Bank Muamalat Indonesia, Tbk. mempertimbangkan apakah dengan menempatkan mesin ATM tersebut produktif atau tidak. Jika penempatan mesin ATM yang dilakukan PT Bank Muamalat Indonesia, Tbk. tidak produktif (jarang digunakan) karena lokasi penempatan yang tidak strategis atau ditempatkan di tempat yang sepi, maka PT Bank Muamalat Indonesia, Tbk. akan mengurangi mesin ATM yang dianggap tidak produktif tersebut guna menghindari ketidakefisienan biaya-biaya yang dikeluarkan terkait mesin ATM yang tidak produktif.

c. Efisiensi penggunaan peralatan dan perlengkapan kantor

PT Bank Muamalat Indonesia, Tbk. menerapkan program paperless, yaitu upaya yang dilakukan untuk menghemat penggunaan kertas. Caranya yaitu dengan digitalisasi dokumen-dokumen dan datadata. Lalu dalam melakukan print, sebisa mungkin hanya mencetak dokumen yang dianggap benarbenar penting dan diperlukan. Kemudian dalam membuat konsep/draft, memakai ulang kertas yang satu sisinya belum terpakai. Surat-surat pemberitahuan atau pengumuman dibuat di email. Dengan demikian, di samping menghemat penggunaan dan biaya pembelian kertas, PT Bank Muamalat Indonesia, Tbk. juga dapat sedikit menghemat biaya printer dan biaya listrik, serta efisien waktu dan tenaga dalam pencarian dokumen atau data yang diperlukan. PT Bank Muamalat Indonesia, Tbk. juga mempertimbangkan biaya pembelian, biaya perawatan, upah teknisi, serta biaya listrik dalam penggunaan mesin fotokopi, mesin jilid, komputer, printer, dan proyektor. PT Bank Muamalat Indonesia, Tbk. juga menegaskan kepada karyawan/staff agar menggunakan telepon pada masingmasing meja kerja secara bijak sesuai kepentingan kantor. Akses internet kantor juga dibuat dengan penerapan ID dan password dalam penggunaannya, hanya karyawan atau staff yg memiliki ID dan password yang dapat menggunakan akses internet kantor, sehingga tidak sembarang orang atau nasabah menggunakan akses internet kantor dengan bebas. Dengan upaya tersebut biaya tagihan internet dapat ditekan.

d. Penerapan sistem branchless banking

PT Bank Muamalat Indonesia, Tbk. berupaya tetap hadir dengan pelayanan prima dengan melakukan upaya menjaring, memfasilitasi, dan melayani nasabah yang kesulitan menemukan waktu luang untuk melakukan transaksi melalui bank, nasabah yang tinggal atau beraktifitas jauh dengan kantor cabang Bank Muamalat, atau nasabah yang menginginkan kemudahan dan kepraktisan. PT Bank Muamalat Indonesia, Tbk. mengembangkan penerapan branchless banking, yaitu layanan keuangan atau perbankan tanpa kantor cabang. Mulai fitur internet banking, mobile branch banking, dan mobile banking guna efisiensi biaya, tenaga, waktu, dan ruang baik bagi pihak bank maupun nasabah. Dengan dikembangkannya penerapan branchless banking, maka tanpa perlu harus ke kantor cabang pun nasabah dapat dapat melakukan transaksi, nasabah dapat tetap terlayani. Dengan adanya penerapan branchless banking, jumlah kantor cabang PT Bank Muamalat Indonesia, Tbk. dapat dikurangi, khususnya kantor-kantor cabang yang kurang produktif karena terbantu dengan penerapan branchless banking. Dengan demikian, penerapan branchless banking yang dilakukan PT Bank Muamalat Indonesia, Tbk. dapat membantu mengefisienkan/mengurangi biaya-biaya yang terkait dengan operasional kantor cabang.

e. Efisiensi biaya tenaga kerja/upah

PT Bank Muamalat Indonesia, Tbk. melakukan efisiensi terhadap biaya tenaga kerja dengan cara melakukan perampingan jumlah tenaga kerja yang dimiliki. Diterapkannya sistem branchless banking juga berpengaruh terhadap perampingan jumlah tenaga kerja. Dengan adanya branchless banking, membuat jumlah kantor-kantor cabang dikurangi. Jika jumlah kantor-kantor cabang dikurangi, maka otomatis PT Bank Muamalat Indonesia, Tbk. juga melakukan perampingan jumlah tenaga kerja guna efisiensi biaya tenaga kerja. PT Bank Muamalat Indonesia, Tbk. juga jeli dalam melakukan perekrutan karyawan/staff dan selektif dalam merampingkan jumlah tenaga kerja. Karyawan/staff yang kompeten dan memiliki peran penting bagi perusahaan akan dipertahankan dan sebaliknya, 
tenaga kerja yang posisinya tidak terlalu diperlukan oleh perusahaan akan diberhentikan guna memangkas biaya tenaga kerja dan memaksimalkan keuntungan/laba.

f. Efisiensi kendaraan operasional

PT Bank Muamalat Indonesia, Tbk. melakukan penghematan biaya-biaya terkait kepemilikan kendaraan operasional dengan cara membatasi jumlah kepemilikan kendaraan operasional dan menegaskan agar menggunakan kendaraan operasional secara bijak sesuai keperluan dan kepentingan kantor saja. Dalam memiliki unit kendaraan operasional, dibutuhkan modal yang tidak sedikit. Setelah itu, ada beberapa biaya-biaya yang perlu diperhitungkan oleh PT Bank Muamalat Indonesia, Tbk. seperti biaya perawatan atau servis, biaya pergantian suku cadang, biaya bensin, biaya perjalanan, upah sopir, pajak kendaraan, serta perlu dipikirkan juga setiap kendaraan pasti mengalami penyusutan. Semakin banyak kendaraan operasional yg dimiliki PT Bank Muamalat Indonesia, Tbk., maka akan bertambah pula beban yang ditanggung oleh PT Bank Muamalat Indonesia, Tbk., terlebih lagi apabila kendaraan operasional tersebut jarang dimanfaatkan. Beban tersebut akan berpengaruh terhadap perolehan laba PT Bank Muamalat Indonesia, Tbk.

\section{Hambatan yang Dialami dalam Melakukan Penerapan Strategi Efisiensi Biaya pada PT Bank Muamalat Indonesia, Tbk.}

a. Banyaknya jumlah pegawai tetap yang dimiliki

Dalam upaya bank untuk merampingkan jumlah tenaga kerja yang dimiliki, ternyata banyak ditemui karyawan/staff yang dikontrak tetap. Hal ini tentu menjadi hambatan untuk dapat meminimalisir biaya tenaga kerja dan memaksimalkan laba/keuntungan serta membuat PT Bank Muamalat Indonesia, Tbk. bingung mengenai nasib pegawai tetapnya ke depan. Hal ini juga dapat menjadi pemicu terhambatnya laju pengembangan penerapan sistem branchless banking yang sedang dikembangkan oleh PT Bank Muamalat Indonesia, Tbk.

b. Masih adanya nasabah yang kurang cocok dengan penerapan branchless banking

Di tengah upaya PT Bank Muamalat Indonesia, Tbk. dalam mengembangkan penerapan sistem branchless banking guna efisiensi biaya, tenaga, waktu, dan ruang, ada beberapa kendala yang dijumpai, seperti nasabah yang masih awam dengan teknologi yang diterapkan, nasabah masih merasa tidak aman dan nyaman dengan penerapan branchless banking sehingga tingkat kepercayaan nasabah terhadap penerapan branchless banking masih rendah, serta nasabah yang lebih menyukai operasional bank yang seperti biasanya dibandingkan dengan sistem branchless banking.

c. Jumlah kendaraan operasional yang dimiliki tidak efisien dan sering kali disalahgunakan

Dalam upaya penghematan yang dilakukan terhadap biaya-biaya yang berhubungan dengan kendaraan operasional, ada beberapa kendala yang dialami PT Bank Muamalat Indonesia, Tbk. yaitu kendaraan operasional yang dimiliki terlalu banyak yang lebih sering terparkir daripada dioperasikan/dimanfaatkan. Keberadaan kendaraan operasional PT Bank Muamalat Indonesia, Tbk. kurang diperlukan. Lalu terkadang ada juga pegawai/staff yang menyalahgunakan kendaraan operasional bank, yaitu menggunakan kendaraan operasional tidak sesuai peruntukkannya. Bukan untuk kepentingan kantor melainkan digunakan juga untuk keperluan pribadi.

3. Solusi yang Dilakukan dalam Menghadapi Hambatan terkait Penerapan Strategi Efisiensi Biaya pada PT Bank Muamalat Indonesia, Tbk.

a. Memberi opsi kepada pegawai untuk melanjutkan kerja atau berhenti dengan pemberian pesangon Solusi yang dilakukan PT Bank Muamalat Indonesia, Tbk. dalam mengatasi hambatan perampingan jumlah pegawai guna efisiensi biaya tenaga kerja dan mengoptimalkan penutupan kantor cabang yang kurang produktif yaitu dengan cara memberi opsi/pilihan kepada pegawai untuk melanjutkan kerja dengan disalurkan ke kantor pusat atau anak perusahaan, atau berhenti dengan pemberian pesangon.

b. Sosialisasi dan promosi layanan branchless banking serta melakukan cross selling di setiap transaksi PT Bank Muamalat Indonesia, Tbk. menekankan pada seluruh pegawai khususnya pada bagian CS (Customer Service) agar giat melakukan pengenalan dan promosi lebih mendalam mengenai keuntungan dan manfaat yang diperoleh dari penggunaan layanan yang disediakan perbankan ini, serta tidak lupa selalu melakukan cross selling (penawaran) untuk menggunakan salah satu layanan/fitur branchless banking dalam setiap transaksi atau pembukaan rekening yang dilakukan nasabah.

c. Menjual sebagian kendaraan operasional yang dimiliki dan memperketat pengawasan penggunaannya

Nidaul Izzah ... (Penerapan Strategi Cost Efficiency (Efisiensi Biaya) Pada Pt Bank Muamalat ...) 
Solusi yang dilakukan PT Bank Muamalat Indonesia, Tbk. atas kendaraan-kendaraan operasional yang jarang digunakan/dimanfaatkan yaitu mencoba melelang kendaraan-kendaraan operasional tersebut agar beban yang ditanggung PT Bank Muamalat Indonesia, Tbk. terkait kendaraan operasional dapat dikurangi. Serta untuk permasalahan kendaraan operasional yang tidak digunakan sebagai mana mestinya oleh pegawai/staff, PT Bank Muamalat Indonesia, Tbk. melakukan pencatatan terkait penggunaan kendaraan operasional yang dimiliki bank. PT Bank Muamalat Indonesia, Tbk. melakukan pencatatan mengenai siapa yang menggunakan kendaraan operasional tersebut, lalu untuk keperluan apa, kapan digunakan, dan tempat tujuan. Sehingga pengunaan kendaraan operasional dapat efektif sesuai tujuan kepentingan kantor.

\section{SIMPULAN}

Berdasarkan pembahasan di atas dapat disimpulkan sebagai berikut:

1. Penerapan strategi efisiensi biaya (cost efficiency) yang diterapkan oleh PT Bank Muamalat Indonesia, Tbk. diantaranya yaitu melakukan penutupan jaringan (kantor-kantor cabang) yang kurang produktif, melakukan pengurangan jumlah penyebaran mesin-mesin ATM yang tidak produktif, efisiensi penggunaan peralatan dan perlengkapan kantor, melakukan penerapan sistem branchless banking, efisiensi biaya tenaga kerja/pegawai, serta efisiensi kendaraan operasional.

2. Hal yang menghambat penerapan strategi efisiensi biaya pada PT Bank Muamalat Indonesia, Tbk. yaitu: Banyaknya jumlah pegawai tetap yang dimiliki, Masih adanya nasabah yang kurang cocok dengan penerapan branchless banking, Jumlah kendaraan operasional yang dimiliki tidak efisien dan sering kali disalahgunakan oleh pegawai (bukan untuk kepentingan kantor)

\section{SARAN}

1. Sebaiknya PT Bank Muamalat Indonesia, Tbk. menginventarisasi data kepegawaian dan menyusun rencana SDM sesuai dengan kebutuhan.

2. Melakukan sosialisasi kepada nasabah untuk penerapan sistem branchless banking,

3. Untuk lebih menghemat biaya terkait kendaraan operasional, sebaiknya PT Bank Muamalat Indonesia, Tbk. menjual kendaraan miliknya dan dapat bekerja sama dengan pegusaha yang bergerak di bidang rental mobil,

\section{DAFTAR PUSTAKA}

Amirullah. 2015. Manajemen Strategi. Jakarta: Mitra Wacana Media.

Assauri, Sofjan. 2016. Strategic Management. Jakarta: Rajawali Pers.

Firmansyah, Iman. 2014. Akuntansi Biaya itu Gampang. Jakarta: Dunia Cerdas.

Halim, Abdul. 2016. Dasar-Dasar Akuntansi Biaya. Yogyakarta: BPFE.

Makmur. 2013. Patologi serta Terapinya dalam Ilmu Administrasi dan Organisasi. Bandung: Refika Aditama.

Pella, Darmin Ahmad. 2016. Problem Implementasi Strategi. Jakarta: Aida Infini Maksima.

Priansa, Donni Juni dan Agus Garnida. 2015. Manajemen Perkantoran Efektif, Efisien, dan Profesional. Bandung: Alfabeta.

Rachmat. 2014. Manajemen Strategik. Bandung: Pustaka Setia.

Salman, Kautsar Riza. 2016. Akuntansi Biaya. Jakarta: Indeks.

Sedarmayanti. 2017. Manajemen Perkantoran Modern. Bandung: Mandar Maju. 